\title{
THE INDONESIAN FINANCIAL CRISIS: FROM BANKING CRISIS TO FINANCIAL SECTOR REFORMS, 1997-2000
}

\section{Shalendra D. Sharma'}

In mid-1998, a World Bank study grimly noted that "Indonesia is in deep economic crisis. A country that achieved decades of rapid growth, stability, and poverty reduction is now near economic collapse ... no country in recent history, let alone one the size of Indonesia, has ever suffered such a dramatic reversal of fortune." 2 There is bitter irony in Indonesia's fall from grace. Long hailed as a model of successful economic development, it was widely predicted to escape the fate of Thailand. ${ }^{3}$ Between June-August 1997, as Thailand's economy unraveled and the virulent Asian flu sent shock waves through the region, the Indonesian economy remained relatively stable-a veritable rock in the stormy sea. Even the World Bank remained upbeat about the short-term outlook, believing that a widening of the intervention band would be sufficient to ward off contagion. 4 The Indonesian government, which received much praise for its swift and decisive response to the crisis, went to great lengths to assure jittery investors "that Indonesia was not Thailand." Then the unthinkable happened.

1 The author would like to thank Bank Indonesia officials in Jakarta for providing valuable data used in this paper and an anonymous reviewer of this journal for insightful comments on an earlier draft of this paper. The author is responsible for any remaining errors.

2 World Bank, Indonesia in Crisis: A Macroeconomic Update (Washington, DC: The World Bank, 1998 ) p. 1.

${ }^{3}$ Furman and Stiglitz find that Indonesia's crisis was the least predictable within a sample of thirty-four troubled countries. See Jason Furman and Joseph Stiglitz, "Economic Crises: Evidence and Insights from East Asia," Brookings Papers on Economic Activity, 2 (1998): 1-135.

${ }^{4}$ World Bank, Indonesia: Sustaining High Growth with Equity (Washington, DC: The World Bank, 1997). 
Indonesia suddenly succumbed to the contagion, and, measured by the magnitude of currency depreciation and contraction of economic activity, it emerged as the most serious casualty of Asia's financial crisis. ${ }^{5}$

What happened? Why did Indonesia (and the other high-performing Asian economies) collapse like hollow dominoes? In the numerous post-mortems that have followed, analysts have identified a number of related factors behind the region's dramatic reversal of fortune. In the case of Indonesia, the variable that soon acquired particular salience was "crony capitalism." Initially popularized by the Economist, the term quickly took a life of its own. Soon thereafter, the distinguished MIT economist, Paul Krugman, would argue that crony capitalism lay the root of Indonesia's-and indeed, East Asia's-financial woes. Krugman describes the innerworkings and manifestations of the insidious crony capitalism in evocative prose.

... how Asia fell apart is pretty familiar . . . the region's downfall was a punishment for its sins. We all know now what we should have known even during the boom years: that there was a dark underside to "Asian values," that the success of too many Asian businessman depended less on what they knew than on whom they knew. Crony capitalism meant, in particular, that dubious investments - unneeded office blocks outside Bangkok, ego-driven diversification by South Korean chaebol-were cheerfully funded by local banks, as long as the borrower had the right government connections. Sooner or later there had to be a reckoning. ${ }^{7}$

Krugman's emphasis on crony capitalism, while not without merit, is too simplistic. After all korupsi, kolusi, and dan nepotisme (corruption, collusion and nepotism) have long been pervasive in Indonesia. ${ }^{8}$ It was hardly an obstacle when Indonesia notched up impressive economic growth rates for some three decades prior to the crisis. Back then, crony capitalism was politely referred to as the "government-private sector nexus" and viewed as a unique feature of the East Asian "developmental states" and even a necessary prerequisite for development. Rather, this essay argues that a more nuanced understanding of Indonesia's economic crisis can be gained by differentiating between the "sources of vulnerability" and the "precipitating" factors. A careful review of the events leading to the crisis shows that both these factors converged during the critical period between late August 1997 and March 1998-and practically everything that could go wrong did over these months. The greatest source of vulnerability - indeed, the fundamental weakness-lay in Indonesia's over-guaranteed, but under-capitalized and under-regulated, banking sector. The precipitating factors were the contagion, but more importantly, poor macroeconomic management by the Suharto regime, and, to a lesser extent, the International Monetary Fund (IMF) exacerbated the crisis.

\footnotetext{
5 An estimated contraction of 15 percent in output occurred in 1998. This figure is among the most dramatic economic collapses recorded since the Great Depression.

6 "Economics Focus: Why Did Asia Crash?," Economist, January 10-16, 1998, p. 11.

7 Paul Krugman, "Saving Asia: Its Time to Get Radical," Fortune, September 7, 1998, p. 17.

8 See, Dwight King, "Corruption in Indonesia: A Curable Cancer," Journal of International Affairs 53,2 (Spring 2000): 603-624; and Adam Schwarz, A Nation in Waiting: Indonesia's Search for Stability (Boulder, CO: Westview Press, 2000).
} 


\section{The Background}

The fact that nobody predicted Indonesia's impending collapse is hardly surprising. Hill notes that before the crisis "almost every technical economic indicator looked safe." Indeed, for a country that was dismissed during the 1950 s as a "chronic dropout" and one that "must surely be accounted the number one failure among the major underdeveloped countries," Indonesia's economic development prior to the crisis was nothing short of miraculous. ${ }^{10}$ Economic growth averaged 7 percent between 1970 and 1989 and 8 percent between 1990 and 1996. This growth occurred alongside substantial industrialization and structural change, as agriculture's share of GDP (Gross Domestic Product) declined from 55 percent in 1965 to 19.4 percent in 1990, while the share of manufactures in GDP rose from 8 percent to 20 percent by $1990 .^{11}$ By 1993, manufactured exports reached US $\$ 21$ billion and accounted for 53 percent of total exports. ${ }^{12}$ Moreover, by the late 1980 s, the economy had become more tradedependent, with total trade flows as a percentage of GDP rising sharply from 14 percent in 1965 to 54.7 percent in 1990 . These developments increased the capacity of the economy to mobilize savings, as reflected in the rise of national savings as a percentage of GDP from 7.9 percent in 1965 to 26.3 percent in $1990 .{ }^{13}$ Equally impressive, the quality of life for the average Indonesian improved greatly, as per capita income rose from US\$75 in 1966 to US\$1,200 in 1996. These gains were spread fairly equitably. For example, between 1976 and 1990 income per person in the poorest quintile of Indonesia's population grew by 5.8 percent per year, whereas the average income of the entire population grew by 4.9 percent per year. To put this success in some comparative context: in 1967 per capita income in Indonesia was less than onehalf that of India, Nigeria, or Bangladesh. By mid-1997, it was five times that of Bangladesh, four times that of Nigeria, and three and a half times that of India. ${ }^{14}$ With such growth, the proportion of population living below the official poverty line declined from 64 percent to an estimated 11 percent between 1970 and 1996-one of the largest reductions in poverty recorded anywhere in the world during the period. Other socioeconomic indicators bear out this success. Infant mortality declined from 145 per 1,000 live births in 1970 to 53 per 1,000 in 1995, life expectancy rose from 46 to 63 years during the same period, and the country achieved universal primary education in 1995. While Java-in particular, greater Jakarta-was the major beneficiary, the benefits of economic growth extended to all of Indonesia's twenty-

\footnotetext{
${ }^{9}$ Hal Hill, The Indonesian Economy in Crisis: Causes, Consequences and Lessons (Singapore: The Institute of Southeast Asian Studies, 1999), p. 8.

10 Quotes are cited in Hal Hill, The Indonesian Economy Since 1966 (New York: Cambridge University Press, 1996), p. 1.

11 K. S. Jomo, Southeast Asia's Misunderstood Miracle: Industrial Policy and Economic Development in Thailand, Malaysia and Indonesia (Boulder: Westview Press, 1997), p. 133.

12 World Bank. World Development Report: 1996 (New York: Oxford University Press, 1996), p. 216.

13 Jomo, Southeast Asia's Misunderstood Miracle, p. 133.

14 Lloyd Kenward, "Assessing Vulnerability to Financial Crisis: Evidence from Indonesia," Bulletin of Indonesian Economic Studies 35,3 (1999): 71-95.
} 
seven culturally diverse and far-flung provinces. ${ }^{15}$ Mills sums up Indonesia's achievements in these words:

Indonesia's growth rate over the past twenty-five years has transformed a desperately poor society in which malnutrition, illiteracy and infant mortality were widespread into one with a large middle class, one in which nearly all children are educated and in which infant mortality and malnutrition have decreased dramatically. The benefits of such relatively rapid growth are not shared equally in any society, but all major groups benefitted greatly: farmers, factory workers, industrialists, small business owners, government employees and the urban poor. ${ }^{16}$

One of the repeated boasts of the Suharto regime was that it had defeated the rampant hyper-inflation of the Sukarno era, and that it had managed to keep budget deficits low and in balance. ${ }^{17}$ Indeed, prudent macroeconomic management kept the budget broadly balanced for an unprecedented thirty years - or the entire length of the Suharto era. Again, it was effective economic management that helped Indonesia steer through the difficulties of the steep oil price increases and declines in the 1970s and 1980s, and that kept the macro-economy largely in balance right up to the onset of the crisis in mid-1997. As noted earlier, the government essentially proscribed domestic financing for the budget, a strategy that kept both expenditures and monetary growth under relative control. Since the mid-1980s, inflation was kept within single digits, and on the eve of the crisis was about 6 percent. ${ }^{18}$ Compared to deficits in Thailand and Malaysia, Indonesia's current account deficit in the 1990s averaged only 2.6 percent of GDP. In fact, not once in any year between 1990 and 1996 did its annual current account deficits ever exceed the average over the period 1983-89. Thus, the deficit on the current account of the balance of payments looked manageable. Also, unlike in Thailand, there was no serious exchange rate misalignment, as Indonesia's exchange rate policy was gradually being relaxed (via widening of the intervention band) by Bank Indonesia, the country's central bank. Moreover, international reserves, both in absolute terms and in months of merchandise imports, were comfortable and rising; the external debt to GDP ratio was gradually declining and was appreciably lower than during the difficult adjustment period of the mid-1980s. And, with the exception of 1990 , Indonesia had an excess of private savings over investment in the period 199096. The budget surplus averaged over 1 percent in the four years previous to the crisis,

15 See Schwarz, A Nation in Waiting, and World Bank, Indonesia in Crisis, p. 75.

16 Edwin Mills, Grozth and Equity in the Indonesian Economy (Washington, D.C.: The United StatesIndonesia Society, 1995), Background paper, no. 1, p. 7.

17 Hollinger writes that "in the early years of the Soeharto administration a new foundation for fiscal policy was put into place: the so-called 'balanced budget principle' which was enacted into law. This still remains today as the guiding rule on the budget and is embodied in each year's annual budget law as passed by parliament. 'Balanced' has a specific meaning in the Indonesian policy context. The requirement is that the total of government expenditures, including both the 'routine' expenditures and the 'development' expenditures into which the Indonesian budget is divided, cannot exceed the total of tax revenues collected domestically plus official foreign aid." William Hollinger, Economic Policy under President Soeharto: Indonesia's Twenty-Five Year Record (Washington, DC: The United States-Indonesia Society, 1996), p. 20.

18 Ross McLeod, "Indonesia's Crisis and Future Prospects," in Asian Contagion: The Causes and Consequences of a Financial Crisis, ed. Karl D. Jackson (Boulder, CO: Westview Press, 1999), p. 209. 
and credit growth was modest. ${ }^{19}$ In short, the traditional economic fundamentals looked sound.

\section{Sources of Vulnerability}

With such an enviable record of development and seemingly sound fundamentals, what went wrong? The roots of the crisis can be traced back to the mid-1980s, when Indonesia embarked on an ambitious economic reform program. The reforms were designed to diversify the economy in order to reduce its dependence on the oil sector, encourage the development of a competitive non-oil export oriented industrial base that would absorb the rapidly growing labor force, and expand the role of the private sector, including foreign capital. Key elements of the reform measures between 19851996 included: (a) gradual liberalization of direct investment inflows to promote nonoil exports and economic diversification; (b) maintenance of a competitive exchange rate; (c) trade liberalization and tariff reform; (d) improvements in monetary management; (e) financial sector reform through liberalization of external inflows; $(f)$ the promotion of competition in the banking sector; and (h) encouraging the growth of the capital market by extending the role of the market in raising funds for investments and lengthening the maturity of money-market instruments. Further, in 1989 the authorities liberalized portfolio capital inflows by eliminating quantitative limits on banks' borrowing from nonresidents. Foreigners were allowed to own up to 49 percent of the shares issued by listed domestic companies (except banks), while domestic companies were allowed to raise funds by selling securities in local and international stock and bond markets. In 1990, restrictions on direct investments inflows were further relaxed, and foreign direct investors were allowed to sell foreign exchange directly to commercial banks instead of through the central bank, and to purchase securities on the stock market and on the over-the-counter bourse. However, as the following sections will show, rapid liberalization implemented without putting the necessary prudential regulations in place, combined with haphazard implementation of the reform measures, made Indonesia highly vulnerable to economic shocks.

Indonesia's seemingly endless growth potential and its adoption of market-friendly economic policies attracted foreign investors. Capital inflows increased almost two and one-half times from 1990-94, reaching US $\$ 14.7$ billion. ${ }^{20}$ Overall, between 199096, Indonesia experienced a surge in capital inflows averaging about 4 percent of GDP. Although not as large as the inflows received by Thailand (10 percent of GDP) and Malaysia ( 9 percent of GDP), cumulatively it still represented a large volume of capital for the economy effectively to absorb. Indeed, by mid-1997, Indonesia's total debt outstanding to foreign commercial banks amounted to US $\$ 59$ billion. ${ }^{21}$ What made Indonesia particularly vulnerable was the maturity structure of the foreign borrowing. According to the Indonesian government's own figures, by the end of June 1997, out of

\footnotetext{
19 World Bank, Indonesia: Sustaining High Growth with Equity.

20 Anwar Nasution, "The Financial Crisis in Indonesia," in East Asia's Financial System: Evolution and Crisis, ed. Seiichi Masuyama, Donna Vandenbrink, and Chia Siow Yue (Singapore: Institute of Southeast Asian Studies, 1999), p. 76.

21 Steven Radelet, "Indonesia: Long Road to Recovery," unpublished paper, Harvard Institute for International Development (March 1999), p. 3.
} 
the US $\$ 140$ billion (about 60 percent of GDP) in external debt, approximately US $\$ 33$ billion was short-term debt with maturities due within one year. ${ }^{22}$ In addition to this amount, Indonesian firms also took out large lines of short-term credit in foreign currencies both directly from foreign lenders and from Indonesian banks-greatly adding to their foreign currency exposure. By contrast, foreign exchange reserves in mid-1997 stood at about US\$20 billion. In other words, short-term debts owed to foreign commercial banks were about 1.75 times the size of Indonesia's total foreign exchange reserves. ${ }^{23}$

The massive inflow of short-term capital was no accident. Indonesia's exchange rate system made short-term debt particularly attractive. From the mid-1980s until August 14, 1997, the Indonesian government maintained an intervention band system (the so-called "crawling peg regime") under which the government pledged to intervene in the markets through means such as foreign exchange purchases and interest rate adjustments-if the rupiah depreciated or appreciated against the US dollar beyond a set percentage. The authorities typically targeted the nominal depreciation of the rupiah against the dollar at between 3-5 percent per annum. There was little variation in this, as Bank Indonesia intervened in the foreign exchange market by buying and selling the rupiah in an intervention band around the central rate. The reasoning behind such an activist policy was to stabilize the real exchange rate, thereby discouraging speculative capital inflows and giving monetary authorities greater flexibility to control monetary aggregates. However, the predictability of the exchange rate made short-term dollar loans seem less risky, and therefore much more attractive. For example, an Indonesian bank borrowing in US dollars simply could compare the cost of purchasing a hedging instrument with the maximum depreciation of the rupiah against the US dollar permitted under the intervention band during the term of the loan. Thus, hedging the currency exposure only would be economically justified when the cost of the hedging instrument was less than the maximum potential depreciation of the rupiah under the intervention band system. Because short-term funding on an unhedged basis was so attractive, and because borrowers were led to believe that the expected losses from currency depreciation would be less than the cost of hedging foreign borrowings, the majority of the banking sector's foreign borrowing remained unhedged. As Radelet notes, "this predictability [of the exchange rate] also undercut the incentives for firms to hedge against their exposure to exchange rate movements. According to one estimate, hedging added about 6 percentage points to the cost of borrowing. Very few firms covered their exposure." 24 This mis-pricing of foreign credits, combined with the increased supply of funds in the global financial markets, contributed to very large capital inflows and created vulnerability for firms with substantial foreign exchange exposure.

In addition, domestic firms found short-term foreign currency loans appealing since they carried relatively lower interest rates. In fact, firms assumed that they would be able easily to roll over their loans when they fell due-after all, this is what they had done for several years before the crisis. Radelet aptly notes that Indonesia's

22 IMF. "Letter of Intent: Indonesia-Memorandum of Economic and Financial Policies," (1997) accessed on June 10, 2000: http://www.imf.org/external/np/loi/103197.HTM

23 Radelet, "Indonesia: Long Road to Recovery," p. 3.

24 Radelet, "Indonesia: Long Road to Recovery," pp. 3-4. 
vulnerability was all the greater because its largest creditors were Japanese banks, which provided about 40 percent of the total credit from foreign banks. ${ }^{25}$ The underlying weaknesses of Japanese banks made them more likely to try to pull their loans quickly once the crisis began. Indeed, this is precisely what happened. In midAugust 1997, as Thailand reached agreement with the IMF on its first program, Japanese banks agreed to keep US $\$ 19$ billion in trade and other credit facilities open for certain Thai commercial bank borrowers. Not wanting to be caught again in similar situations in other countries in the region, the Japanese banks began to withdraw their credits from Indonesia, Malaysia, Korea and other countries-helping to further spread the crisis.

Indonesia's crawling peg regime unintentionally contributed to another problem: a modestly overvalued exchange rate and slowing export growth. This trend sharply increased after the 1987 Plaza Accord, which brought down the value of the US dollar and ushered in a new era of the appreciating yen. Between 1985 and 1988, the yen almost doubled in value vis-à-vis the dollar and other Asian currencies tied to the dollar. More broadly, by 1988, the yen was almost 30 percent above its average for the 1980-85 period on an inflation-adjusted, trade-weighted basis. ${ }^{26}$ By the mid 1990s, the era of the strong yen was over, as indicated by the sharp appreciation of the dollar in 1995, especially its appreciation vis-à-vis the yen. As the dollar rose relative to the yen, the currencies of the countries tied to the dollar (like Indonesia) rose in comparison with the yen also. ${ }^{27}$ Radelet notes that between 1990 and mid-1997, the rupiah appreciated approximately 22 percent in real terms, while growth in Indonesia's non-oil exports slowed from an annual average of 26 percent in 1991-92 to 14 percent between $1993-95$ to just 10 percent in 1996-97.28 This modest overvaluation and export slowdown, although smaller than in the other crisis-affected countries, clearly pointed toward the need for some moderate adjustments to reestablish the international competitiveness of Indonesian firms.

Vulnerability also resulted from the way the capital inflows were utilized. The massive capital inflows soon created problems of absorption. While capital was invested in productive investments such as infrastructure development, electricity generation, and heavy industries such as petrochemicals and automobile assembly, a significant portion also found its way into the non-tradeable sector-in particular, real estate-fueling speculative overbuilding, particularly in the greater Jakarta area. ${ }^{29}$ Why real estate? The surge in private capital inflows relative to the size of the equity market quickly drove equity prices up. Investments in real estate-especially, housing, hotels and tourist resorts, amusement parks, golf courses, and shopping malls-looked

\footnotetext{
25 Radelet, "Indonesia: Long Road to Recovery," p. 4.

26 Takatoshi Ito and Tokuo Iwaisako, "Explaining Asset Bubbles in Japan," Monetary and Economic Studies, Bank of Japan, vol. 14, no. 1 (July 1996), pp. 143-93.

27 After hitting a historical high of eighty yen to the dollar in June 1995, the yen experienced a downward trend, falling to 127 yen to the dollar in April 1997-or just before the Asian crisis broke. The yen's sharp depreciation led to a marked deterioration in East and Southeast Asia's export performance and current account imbalances in 1996, paving the way for the currency crisis.

28 Radelet, "Indonesia: Long Road to Recovery," p. 4.

29 H. Sender, "Space Race: Jakarta's Real Estate Market Headed for Trouble?," Far Eastern Economic Review, August 4, 1994, pp. 55-56.
} 
promising. Foreign lenders able to purchase stock, commercial paper, and real estate easily were only too eager to finance these projects, not only because they seemed to be good investments, but also because many of these projects were controlled either directly or indirectly by Suharto's family and their cronies; they assumed that the projects carried an implicit guarantee from the Indonesian government.

Perhaps Indonesia's greatest vulnerability lay in its weak financial system, especially its dangerously undercapitalized and poorly supervised banks. What explains this weakness and why was it allowed to persist? A brief background is necessary. While reform of the Indonesian banking system was initiated in 1983 with the abolishment of Bank Indonesia's control over interest rates on deposits and loans, it was in October 1988 that Bank Indonesia enacted a package of major banking reforms known as PATKO '88. ${ }^{30}$ Among other things, PATKO '88 ended segmentation of the financial market, improved market competition, and relaxed the restrictions on the establishment of private and foreign-owned banks, as well as those restrictions on existing banks opening new branches-including the granting of permission to stateowned firms to deposit 50 percent of their short-term funds with private banks, instead of only with state-owned banks. Moreover, it permitted extremely low capitalization, setting the minimum paid-in capital requirement for newly established banks at the rupiah equivalent of US $\$ 5$ million. It also allowed more foreign ownership of domestic assets, abolished the limits on inflow of foreign direct investment and foreign ownership of equities issued in domestic stock markets, and sharply eased bank reserve requirements from 15 percent to 2 percent. Further deregulation in 1989 eliminated the need for Bank Indonesia approval for medium and long-term loans and removed ceilings on offshore loans. ${ }^{31}$ In addition, the government moved to deregulate equity, bond, insurance, and related financial activities. Not surprisingly, by the end of 1996, commercial banks dominated the financial system in Indonesia. Out of a total of 238 commercial banks, there were seven state-owned banks, twenty-seven regional government banks, 160 private banks, thirty-four joint-venture banks, and ten foreign banks. In addition, there were approximately 9,200 rural banks. Nonbank financial institutions included 252 finance companies, 163 insurance companies, about three hundred pension and provident funds, and thirty-nine mutual fund companies. Total assets of the system were equivalent to about 90 percent of GDP. Commercial banks held 84 percent of total assets, while rural banks held about 2 percent. The remaining assets were held by finance companies ( 7 percent of total assets), insurance companies (5 percent), and other nonbank financial institutions held 2 percent. ${ }^{32}$

\footnotetext{
${ }^{30}$ The 1983 reforms were enacted at a time when Indonesia's earnings from oil (its principal export commodity) were declining. In the two-year period, 1982-83, Indonesia's export earnings from oil fell by 24 percent. The Indonesian government recognized that a more efficient and well-developed banking system would help foster the creation of a more diversified national economy. For details, see Michael Bennett, "Banking Deregulation In Indonesia," University of Pennsylvania Journal of International Business Law 16,443 (1995).

31 John Montgomery, "The Indonesian Financial System: Its Contribution to Economic Performance and Key Policy Issues," IMF Working Paper, WP/97/45 (Washington, DC: International Monetary Fund, 1997), pp. 11-12.

${ }^{32}$ Carl-Johan Lindgren, Tomas Balino, Charles Enoch, Anne-Marie Gulde, Marc Quintyn and Leslie Teo, Financial Sector Crisis and Restructuring: Lessons from Asia, IMF Occasional Paper 188 (Washington, DC: International Monetary Fund, 1999), p. 13.
} 
While these reforms succeeded in transforming a closed banking sector dominated by a small number of state-owned banks into a more diverse and competitive system, and they brought benefits to the economy-such as more efficient credit allocation and financial intermediation (not to mention providing Indonesians with many more options for financial services)-banking deregulation also posed challenges that the authorities failed to meet. First, the problem of moral hazard occasioned by explicit or implicit government guarantees induced reckless lending, especially to the wellconnected. Indeed, there was a strong presumption in the financial and business community that neither investors nor lenders would ever bear the full cost of any corporate or bank failure. This belief was fostered by the close links between powerful business groups, who also often controlled financial institutions, and the government. Investors and bankers were led to assume that the government would eventually bail them out if they got into trouble, even in the absence of explicit government guarantees. As Krugman observes, when government actions suggest that there is an explicit guarantee against either bank or corporate failure, such implicit guarantees can trigger asset price inflation and make the financial system vulnerable to collapse. ${ }^{33}$ And, second, the failure simultaneously to develop the necessary prudential supervisory, regulatory, and legal framework (and enforce what regulation did exist) made Indonesia highly susceptible to a system-wide banking crisis.

For example, the financial reforms resulted in a rapid expansion of bank credit-a variable widely regarded in financial markets as an indicator of financial vulnerability, since high credit/GDP ratios weaken the capacity of central banks to push up interest rates in defense of the currency during a crisis. Outstanding bank credit increased by an average of 24.3 percent per year from 1992 to 1996. Part of the credit expansion was financed by foreign borrowing, and when restrictions on lending were lifted, banks began to expand and extend credit to property and real estate, including ambitious and costly infrastructure projects. Bank Indonesia's own figures show that bank lending to the property and real estate sector increased by roughly 40 percent from 1995 to 1996.34 While the competitive, if not speculative, market environment (not to mention the easy availability of bank credit) increased the pressure on banks to lend without careful risk-assessment, Nasution notes that "Indonesia's prudential rules and regulations were poorly implemented and largely unenforced . . . bank credit officers who were reared in the pre-reform environment may have lacked the expertise to evaluate new sources of credit and market risk." 35

Furthermore, officials at the state-owned banks, who viewed their job security and career advancement as being essentially dependent on their ability to satisfy powerful individuals and the well-connected, hardly bothered to assess the creditworthiness of the borrowers. Not surprisingly, in the case of the state-owned banks, risky lending practices were often the result of both explicit and implicit pressure exerted by members of the Suharto family, their cronies, and other high ranking military and government officials, to make loans to favored borrowers. Indeed, the practice of making loans based on political pressure became known as "memo lending" because

\footnotetext{
33 Krugman, "Saving Asia."

34 Soedradjad Djiwandono, The Banking Industry Facing the $21^{\text {st }}$ Century, Bank of Indonesia (1999), (http://www.bi.go.id/intl/speeches/century.htm)

${ }^{35}$ Nasution, "The Financial Crisis in Indonesia," p. 80.
} 
such loans were extended on the basis of a "memo" sent by the powerful and wellconnected. Soon memo lending and other illegal practices led to high levels of nonperforming loans at the state-owned banks. The case of a government-owned development bank, Bank Pembangunan Indonesia (also known by its acronym as Bank Bapindo), is illustrative. In 1994, Bank Bapindo lent some US\$430 million to the Golden Key group, at that time a little known Indonesian conglomerate owned by a businessman Eddy Tansil, with close links with senior military and government officials. The loan was never repaid, and later government investigation alleged that the loan had been extended based on fraudulent documentation and with the complicity of key Bapindo executives and government officials, including former minister of finance, Johannes Sumarlin. ${ }^{36}$ Regulators and central bank supervisors were also involved in fraud and collusion. For example, in the case of commercial paper issued by PT Bank Pacific, PT Bank Arta Prima, and PT Bank Perniagaan, four supervisors of Bank Indonesia were arrested in early August 1997 for allegedly taking bribes during inspections between 1993 and 1996. Nasution provides a macro dimension of the problem:

Despite average annual economic growth of over 6 percent since 1990, the volume of problem loans held by Indonesia's banks remained considerable. In 1995, 8.8 percent of total bank credit outstanding was classified as sub-standard, doubtful, or bad debt. As of November 1996, the bad debt of the banking system amounted to Rp.[rupiah] 10.4 trillion (equivalent to about 2 percent of GDP or around 10 percent of total loans). Of this amount, state-owned banks held Rp. 7.1 trillion (68 percent). ${ }^{37}$

In the case of the private banks, risky lending practices usually involved banks making loans to affiliated companies-which also included affiliated property companies. Specifically, since liberalization increased the attraction of commercial and industrial concerns to the financial sector, many of Indonesia's large business conglomerates opened one or more private banks. Most of these banks were not managed on an independent basis, but as funding sources for the affiliated businesses; they extended loans to suit the funding needs of the businesses, following terms that were dictated by the affiliated businesses' senior office-holders, rather than being based on diligent risk-assessment of the companies' creditworthiness. While there were rules regarding the aggregate amount that a bank could lend to its affiliated companies, there were no clear provisions to enforce the rules. In any case, indirect or intra-group lending could be easily concealed. Thus, loans to affiliated companies were among the riskiest loans held by the private banks. The case of Bank Summa is illustrative. This bank was one of the first private banks established after the enactment by Bank Indonesia of the 1988 banking reforms. Prior to its collapse, Bank Summa was one of the ten largest banks in Indonesia and was owned by the influential Soeryadjaya family, who also had major controlling interest in Astra International, one of Indonesia's largest conglomerates. In 1992, Bank Summa collapsed. At the time of Bank Summa's liquidation, it was estimated that more than 70 percent of its loan portfolio was nonperforming, and that a high percentage of these loans had been made

\footnotetext{
36 For details, see the Economist, "Economy: Bapindo Scandal Highlights Crisis in Banking Industry," Economist Intelligence Unit-Country Report, August 5, 1994.

37 Nasution, "The Financial Crisis in Indonesia," p. 83.
} 
to its affiliated companies. In total, Bank Summa had amassed more than US\$700 million in nonperforming loans. ${ }^{38}$ Nasution notes:

Indonesia's weak market infrastructure, malfeasance, and malversation together have allowed the emergence of so-called "swindle" banks. The typical swindle bank makes loans to non-bank companies owned by its principal owner(s) to finance questionable investment projects, usually at inflated prices. Liabilities of such banks are mainly deposits owned by the general public, liquidity credit from Bank Indonesia, unsecured commercial paper sold to the general public (including foreigners), and equity shares owned by Bank Indonesia and other state-related institutions. ... Such banks typically have negative net worth. ${ }^{39}$

By the early 1990s, Bank Indonesia was quite aware that the country's banks, given their high level of exposure to property companies, faced a potentially disastrous problem. As is well known, investments in property and real estate are long-term and highly risky because they are very sensitive to future growth expectations. In contrast, the liabilities of the banks were mostly short-term and denominated in US dollars, Japanese yen, and other foreign currencies. Also, in many cases, banks had taken no collateral, and those which had taken collateral took a pledge over property as collateral for loans. In any case, they could hardly collect, because a fall in real estate prices would mean that by the time of default the property used to secure the loan would be worth only a small fraction of the outstanding loan principal amount. Moreover, as noted earlier, short-term borrowing from abroad was a relatively inexpensive source of funds, provided that the banks did not incur additional costs purchasing hedging instruments to protect themselves from any depreciation of the rupiah against the currency they had borrowed. Unhedged foreign currency borrowing posed an obvious risk to a bank in that any depreciation of the rupiah during the term of the loan would mean that the amount of rupiah needed to repay the loan on maturity would be far greater than the amount the borrower received upon drawing the loan. In short, Indonesian banks were faced with an unhedged funding mismatch between borrowing short-term from abroad in foreign currency and lending long-term in rupiah. All these asymmetries of the bank's balance sheets added greatly to their overall riskiness.

In an effort to address these problems, the Indonesian government enacted the Banking Law (known as Banking Act No. 7) in 1992. The Banking Law contained provisions designed to restrict the aggregate amount that a bank could lend to affiliated companies to 20 percent of the bank's capital, and it converted some state banks to limited liability companies and permitted them to lend only to nonpriority sectors. In 1995, reserve requirements was raised from 2 percent to 3 percent, effective February 1996. In addition, the minimum capital required for banks with foreign exchange licences was tripled, and the capital adequacy ratio for these banks was raised from 8 percent to 12 percent-with both these measures to be phased in over a five-year period ending in 2001. Bank Indonesia also developed a supervisory system patterned on the United States CAMEL system (Capital, Asset Quality, Management, Earnings, Liquidity), including annual on-site examinations of banks. However, the

38 Tony Shale, "Top-Level Shakeout Needed to Mend the Financial System," Euromoney, June 1993, p. 55.

${ }^{39}$ Nasution, "The Financial Crisis in Indonesia," pp. 85-6. 
90 Shalendra D. Sharma

enforcement of these measures was generally quite lax and violations rampant. Bank Indonesia's own report acknowledged that, as of March 1997, a significant number of banks remained undercapitalized and not in compliance with the prudential rules. While these figures most likely understate the extent of noncompliance, according to Bank Indonesia, fifteen banks did not meet the required 8 percent capital adequacy ratio in April 1996, while forty-one banks did not comply with the legal lending limit, and twelve licensed foreign exchange banks did not meet the rules on net open foreign exchange exposure. ${ }^{40}$ A more illustrative picture of the banks' continued high level of exposure to the property and real estate sector can be drawn from the fact that, during 1996, even as the glut in the property market became apparent and real estate prices began to nosedive, Indonesian banks continued to lend to property companies. In 1997, despite large-scale losses reported by the property industry, bank lending to the property sector totaled about 19.4 trillion rupiah, a 21 percent increase from 1996.41 In July 1997, Bank Indonesia issued a decree that was intended severely to restrict bank credit to real estate developers, but it was too little too late. Undercapitalized and, in large measure, burdened with poorly diversified and badly performing loan portfolios, Indonesia's over-guaranteed but under-regulated banking system lay exposed and highly vulnerable to economic shocks. All it needed was a trigger. The trigger was the contagion from Thailand.

\section{The Trigger and the Fallout}

On July 2, 1997 the Bank of Thailand abandoned the baht's peg to its traditional basket, and the baht immediately depreciated sharply against the US dollar. Pressure then quickly intensified against the Philippine peso and the Malaysian ringgit-each of which received only limited support from their central bank. On July 8, the rupiah came under pressure. Although Indonesia had stronger macroeconomic fundamentals than Thailand (as it pertained to exports and the fiscal balance) and only a modest current account deficit, the rupiah was, nevertheless, vulnerable for two principal reasons. First, there was the huge foreign debt burden of the private Indonesian corporations (much of it short-term and not hedged against exchange-rate changes). Second, the fundamental weakness of the financial and banking sector raised doubts about the government's ability to defend the currency peg.

The Indonesian government's initial reaction to speculation against the rupiah was decisive. Rather than defending its currency and squandering a large portion of its reserves, as central banks in Thailand had done, Bank Indonesia, on July 11, widened the trading band for the rupiah from Rp. 192 (8 percent of the central rate) to Rp. 304 (12 percent of the central rate) in a preemptive move designed to deter speculation. It also limited nonresident transactions in the forward market and introduced an array of tight monetary policies along with administrative measures to limit external borrowings by commercial banks. ${ }^{42}$ Despite the vigorous defense, the rupiah continued

\footnotetext{
40 Montgomery, "The Indonesian Financial System," p. 13.

41 Alistair Hammond, "A Million Indonesian Construction Workers to Lose Jobs in '98," Bloomberg News, December 19, 1997, available in LEXIS, News Library.

42 Bank Indonesia's Monetary Management Director, Dr. C. Harinowo, explained that "the benefit [of widening the rupiah band] is providing us more autonomy to managing monetary policy. We do not need to
} 
to slide, in large part because large domestic conglomerates, fearful that they would not be able to repay their foreign debts if the rupiah fell significantly, rushed to hedge these debts by buying US dollars. By July 21 the rupiah had fallen by 7 percent, in effect sharply depreciating to near the bottom of the new band. In response, on July 23, Bank Indonesia raised interest rates from 12 percent to 13 percent, and it intervened heavily in support of the rupiah. But this was to no avail, as the panic selling of rupiah and assets denominated in rupiah continued. When the rupiah depreciated by 13 percent (from 2,400 per US dollar in July to 2,700 on the August 13), it was the last straw.

On August 14, 1997, the Indonesian authorities, reluctant to squander more foreign reserves, allowed the rupiah to float. ${ }^{43}$ Immediately the rupiah depreciated sharply against the US dollar and other currencies in which the Indonesian banks had borrowed. Because of the depreciation, the amount of rupiah that Indonesian banks earned on their long-term loans to the property sector and other industries was no longer sufficient to service their short-term foreign borrowings. Moreover, the banks could no longer attract new funds from abroad that could be used to repay the shortterm borrowings coming close to maturation. In response, the Indonesian government raised short-term rupiah interest rates in order to attract rupiah deposits and stabilize the currency. For example, on August 11, 1997, the overnight Jakarta interbank rupiah rate (or JIBOR) was 15.8 percent. A week later, on August 18, the overnight JIBOR was 51.4 percent, and by August 22 the overnight JIBOR was 87.7 percent. However this failed to bring much of a reprieve, as the rupiah continued to weaken. The Ministry of Finance responded by cutting government spending through rescheduling some projects and limiting routine expenditures on non-priority items. It also further tightened liquidity by instructing the public sector-including state-owned enterprises-to shift their deposits from (mainly state-owned) commercial banks to Bank Indonesia. However, this also proved ineffective, as the rupiah continued to slide, gaining renewed momentum downward on August 21. In desperation, on August 29, Bank Indonesia issued a new rule limiting the forward sale of dollars to non-residents to US\$5 million in order to reduce currency speculation.

It is not clear if the Indonesian authorities were in consultation with the IMF regarding the tight money policy. Bank Indonesia argued that the tight money policy was necessary to keep inflation under control and to stem the tide of large shifts into dollar holdings by residents. This is similar to the long-held IMF position that stresses the importance of high interest rates in keeping domestic currency holdings attractive, even if it complicates the situation of weak banks. In hindsight, we can recognize that an "overshoot" in the interest rate increase-an increase implemented through the tightening of liquidity by the Indonesian authorities-was very much responsible for the severe financial crisis that ensued. More than anything else, the tight money immediately exposed Indonesia's weak financial and banking systems. Bank runs

be concerned with the exchange rate, which affects monetary aggregates. It gives us a bigger cushion if there are any speculative attacks. It provides us with an experience of a floating-rate regime, but within a narrow confinement." See Callum Henderson, Asia Falling (New York: McGraw-Hill, 1998), p. 127.

43 Soesastro and Basri note that between July 20 and August 13, Bank Indonesia's interventions in the market had depleted the reserves by over US $\$ 1.5$ billion. Hadi Soesastro and Chatib Basri, "Survey of Recent Developments," Bulletin of Indonesian Economic Studies 34,1 (April,1998): 7. 
emerged as early as the second half of August 1999, when the process of "flight to safety" began. Faced with the prospect of widespread bank failures, Bank Indonesia had to scramble quickly to supply banks facing liquidity problems with funds, and by the end of August 1997 it had put up some US $\$ 500$ million for the troubled banks. ${ }^{44}$

The injection of new liquidity and the lowering of short-term interest rates (the JIBOR rate fell to 40 percent in the first week of September) did provide a temporary reprieve. ${ }^{45}$ On September 23, finance minister Mar'ie Muhammad unveiled a comprehensive policy program to deal with the crisis. ${ }^{46}$ The program included: (a) stabilization of the rupiah at a new equilibrium level, (b) strengthening of fiscal policies and fiscal consolidation, (c) reduction of the current account deficit, (d) strengthening of the banking sector, and (e) strengthening of the private corporate sector. To achieve these objectives, the government made a pledge to further "loosen liquidity gradually and in accordance with the situation through fiscal and monetary instruments." Furthermore, it made a commitment to reduce interest rates and cancel or postpone over two hundred public sector-related development projects that would save the government some US\$37 billion. These included the postponement of costly megaprojects, such as construction of the Jakarta Tower, of the bridge between the Sumatra and the Malaysian peninsula, and of the Menara Jakarta bridge. In regards to the banking sector, the government announced its intention to merge state banks and liquidate the insolvent ones. Also, it made a commitment to follow-up quickly on the plan to encourage weak private banks to explore the possibility of merger. Finally, in a dramatic move, the 49 percent foreign ownership limit on Indonesian stocks was scrapped in order to increase the foreign investment in the stock market.

These announcements succeeded in bringing a measure of calm to the markets. As the rupiah stabilized around Rp. 3,000 per US dollar, some thought that the worse was over. However, it was only a temporary reprieve-the calm before the storm. Part of the dilemma was that Indonesia was facing a confidence problem, and despite all the concerted effort, the government failed to restore confidence. However, a bigger problem was that, as ambitious as the finance ministry's program was, it did not go far enough. For example, rather than postponing or dismantling inefficient and profligate monopolies, such as the state-owned aircraft manufacturer Industri Resawat Terbang Nusantara (IPTN), a pet project of the Suharto protégé, B. J. Habibie, or the national car project owned largely by Suharto's youngest son, Hutomo (Tommy) Mandala Putra, the government reaffirmed its commitment to continue to support these projects. ${ }^{47}$ As regional currencies and stock markets continued to plummet, and

44 Soesastro and Basri, "Survey of Recent Developments," p. 9.

45 This measure, of course, reduced the costs incurred by banks borrowing in the interbank market.

${ }^{46}$ Mar'ie Muhammad, "Statement by the Hon. Mar'ie Muhammad at the 1997 World Bank/ IMF Annual Meeting in Hong Kong," IMF press release no. 25, September 23, 1997.

47 The national car policy was promulgated in the Presidential Instruction No. 2/1996 which gave a "pioneer" status to PT Timor Putra Nasional-jointly owned by Suharto's youngest son and KIA Motor Corporation of South Korea. This exclusive status exempted the company from paying 65 percent maximum import duties for car spare-parts, and 35 percent maximum import duty and luxury goods sale tax that make up over 60 percent of the cost of car production in Indonesia. Moreover, to boost the sale of the car, the public sector was required to purchase it. Fully backed by the Indonesian government, Bank Indonesia, and a consortium of four state-owned banks and twelve private domestic banks, the company received an initial 
amidst reports that Indonesian banks and private companies were having great difficulty in meeting their external debt service obligations, the pressure on the rupiah re-intensified. By early October the rupiah had fallen by more than 40 percent since July (the fastest depreciation among the crisis countries), while the Jakarta Stock Market Index dropped by 44 percent. ${ }^{48}$ On October 6, the Indonesian government sold another US $\$ 650$ million in the foreign exchange market to stabilize the external value of the rupiah. ${ }^{49}$ Again, this was to no avail. On October 8, when the exchange rate passed 3,800 rupiah to the U.S. dollar, Indonesia turned to the IMF for "consultation" and "technical assistance." 50

On October 31 (after some three weeks of discussions), the Indonesian government negotiated a financial bailout package totaling some US\$43 billion in international assistance with the IMF and bilateral donors. The package consisted of US\$23 billion of the so-called "first line of funds" negotiated with the IMF and a "second line of funds" negotiated with bilateral donors. These included Japan (US\$5 billion), Singapore (US\$5 billion), United States ( $\$ 3$ billion), Malaysia (US\$1 billion), Australia (US\$1 billion), Brunei (US\$1.2 billion) and China and Hong Kong SAR.51 Of the US\$10 billion from the IMF, US\$3 billion was to be disbursed immediately, and a further US $\$ 3$ billion was to be made available after March 15, 1998, provided the Indonesian government met the program's economic targets. The rest of the money was to be disbursed on a quarterly basis, provided the targets continued to be met. ${ }^{52}$ The entire agreement was to be implemented over a three-year period and carefully monitored jointly by the Indonesian government and the IMF, including experts from the World Bank and the Asian Development Bank.

The mood was one of cautious optimism after the signing of the October 31 agreement. It was widely believed that the agreement would restore investor confidence and arrest the rupiah's continuing plunge. ${ }^{53}$ IMF Managing Director, Michel Camdessus, summed up the prevailing mood when he noted that "these measures should restore confidence in the Indonesian economy and contribute to the stabilization of regional financial markets." 54 Indeed, initially the program received positive response from the market, resulting in the rupiah strengthening from Rp. 3,700

US $\$ 960$ million for its production and assembly facility. King notes that "this cronyism was so brazen ... as to anger even the regime's staunchest supporters." King, "Corruption in Indonesia," p. 617.

48 Soesastro and Basri, "Survey of Recent Developments," p. 10.

49 Nasution, "The Financial Crisis in Indonesia," p. 88.

50 Finance minister Mar'ie Muhammad made it clear that the government was only seeking the IMF's technical assistance, and would explore the possibility of financial support only as a precaution. Indeed, on October 8, the IMF was invited for consultation only, and no explicit request for a loan was made. See Soesastro and Basri, "Survey of Recent Developments," p. 10; also Hill, The Indonesian Economy in Crisis, p. 15.

51 While the technical details of the bilateral assistance were worked out between Indonesia and the individual countries, the United States made it clear that its loans could be drawn upon only if Indonesia followed the agreement with the IMF.

52 IMF, "Indonesian Measures Welcomed as Important Step in Stabilizing Southeast Asian Financial Markets," IMF Survey 26,21 (November 17, 1997).

53 David Liebhold, "Rough Road Ahead," Asian Business 30, 2 (February 1998).

54 IMF, “Camdessus Commends on Indonesia's Impressive Economic Policy Program," IMF Survey 26,20, November 3, 1997. 
94 Shalendra D. Sharma

to Rp. 3,200 per dollar. However, it was too early to celebrate. The economic program the Indonesian government had committed to in its "letter of intent" to the IMF (which now became part of the agreement) was quite extensive. .5 For example, it included, among other things, (a) trade policy reform, in particular, trade deregulation for various commodities via the elimination of BULOG's (Badan Urusan Logistik-Food Distribution Agency) monopoly on import of wheat, wheat flour, soybeans, and garlic effective January 1, 1998; (b) gradual reduction of import tariffs on chemical products, iron and steel, and fisheries products; (c) industry policy reform, such as the elimination of local content program for automobiles by 2000 and the implementation of the WTO decision on the National Car project by 2000; and (d) macroeconomic policy targets for economic growth, inflation rate, current account deficit, and fiscal balance, as well as economic reform measures covering investment and financial institutions. At the core of the latter was the program to reform the banking industry.

Specifically, based on data made available by Bank Indonesia which documented the financial condition of 92 of the 238 banks, representing 85 percent of the assets of the banking system, the IMF and the Indonesian government agreed on a comprehensive bank resolution package consisting of:

(1) intensified supervision, including frequent and detailed reviews, in addition to daily monitoring of key elements like liquidity and foreign exchange exposure for six of the country's largest private banks (market share: 18 percent) in which some critical weaknesses had been identified;

(2) rehabilitation plans for seven small private banks;

(3) conservatorship for three small, severely under-capitalized private banks, and for six insolvent regional development banks (market share 0.4 percent);

(4) transfer of the performing assets for two insolvent state-owned banks (market share: 9.6 percent) to a third state-owned bank; merger of the two insolvent banks and transformation of the resulting entity into an asset recovery agency;

(5) definition and implementation of rehabilitation plans for ten insolvent private banks (market share: 3 percent) that had benefited from a Bank Indonesia-sponsored and legally binding rescue package prior to the crisis, accelerating their return to solvency; and

(6) closure of sixteen small and deeply insolvent private banks (market share: 2.5 percent), with protection limited to small depositors.

In total, the agreement included fifty banks, representing 34.3 percent of the banking system. However, on November 1, 1997 (less than twenty-four hours after reaching the agreement with the IMF), the Indonesian government abruptly suspended the operating licenses of the sixteen banks-in effect, closing them down. ${ }^{56}$ This action

\footnotetext{
55 The "letter of intent" released by the Indonesian government on October 31, 1997 described the policies that Indonesia intended to implement in the context of its request for financial support from the MM. For details, see IMF, "Letter of Intent: Indonesia."

56 The liquidated banks were: Bank Harapan Sentosa; Sejahtera Bank Umum; Bank Andromeda; Bank Pacific; Bank Guna Internasional; Bank Astria Raya; Bank Dwipa Semesta; Bank Jakarta; Bank Industri; Bank Citrahasta Dhanamanunggal; South East Asia Bank; Bank Mataram Dhanarta; Bank Pinaesaan; Bank Anrico; Bank Umum Majapahit Jaya and Bank Kosagraha Semesta.
} 
proved to be disastrous. As Soesastro and Basri note, "the closure of sixteen commercial banks created panic in the country, leading to large withdrawals by depositors even from banks that were generally believed to be healthy. Suddenly, confidence in domestic private banks was shattered." 57 As a result, there was further "flight to quality" as depositors sought to move their funds out of the private banks that were believed to be in trouble into the state banks, which were widely thought to be more secure. Literally overnight many banks lost their deposit base, besides finding that trade and other financial lines from their bank business abroad were terminated. Letters of credit issued by many Indonesian banks were no longer accepted overseas. It seemed that market confidence had been completely lost.

Why did the closure of just sixteen small and insolvent banks with only 2.5 percent of the total banking assets generate such a panic? According to Harvard economist Jeffrey Sachs, it was due to the IMF's "misguided policies." 58 He claims that the closure of the banks was not necessary. By hastily closing banks in an environment where no deposit insurance was in place, the IMF generated panic that quickly became a full-blown financial crisis. Indeed, the closures exacerbated the ongoing liquidity squeeze in financial markets, making it much more difficult for all banks to continue their normal lending operations. The IMF's demand for tighter fiscal and monetary policy when budgets were broadly in balance, and when the economy was already beginning to contract, made little sense. Hal Hill aptly blames the IMF's "scatter-gun approach," which "overloaded the reform agenda, forcing bureaucratically stretched governments to quickly tackle a vast array of highly complex and sensitive policy issues" and which "attempted to resolve banking sector distress too quickly, [thus] aggravating the general loss of confidence." 59

Yet, having said this, it is important to recognize that Sachs is only partly correct and the IMF only partly to blame for Indonesia's financial crisis. While there is little question that pressure from the IMF forced the Indonesian government to take its first significant step toward restructuring the banking sector (by liquidating sixteen of the weakest private banks), the problem was not the closure of these weak banks, per se, but the manner in which it was done. ${ }^{60}$ First, while the agreement mentioned fifty banks, only sixteen were closed-and these sixteen were clearly insolvent on the basis of data provided by the banks to Bank Indonesia. ${ }^{61}$ Since the remaining thirty-four banks were not identified, it created uncertainty among the general public regarding the fate of all other banks. After all, not only was the public generally aware that some well-connected banks were not listed, there was also no deposit insurance in place. ${ }^{62}$

57 Soesastro and Basri, "Survey of Recent Developments," p. 19.

58 Jeffrey Sachs, "The Wrong Medicine for Asia," New York Times, November 3, 1997.

${ }^{59}$ Hill, The Indonesian Economy in Crisis, pp. 52-3.

${ }^{60}$ Indeed, the IMF saw the forced liquidation of the sixteen banks as a sufficiently important step towards reforming the banking system. Thus, on November 5, 1997, the Fund approved the three-year Stand-By Arrangement (totaling US $\$ 10$ billion) - and released the first installment of the promised aid package.

61 Charles Enoch, "Interventions in Banks During Banking Crises: The Experience of Indonesia," IMF Policy Discussion Paper. PDP/00/2. Monetary and Exchange Affairs Department, 2000.

62 In all fairness it should be mentioned that a blanket deposit guarantee was not introduced because of the moral hazard effect. It was believed that the sixteen banks being closed were very small, and hence, there was no need for such a guarantee. 
Nor was there a strategy in place for dealing with the liabilities and assets (both good and bad) of either the closed banks or those that remained open. At the same time, a lack of disclosure regarding the health of remaining banks meant that nothing was done to allay depositors' concerns about the health of the rest of the sector. It is hardly surprising that, given such uncertainty, depositors' initial concern soon ballooned and initiated a full-scale run on the banking system as a whole.

Second, although among the sixteen banks listed for closure was Bank Andromeda (partly owned by one of Suharto's sons, Bambang Trihatmodjo) and Bank Jakarta (partly owned by Suharto's half-brother, Probosutejo), the fact that only the smallest and weakest banks in the country (with less than 2.5 percent of Indonesia's total banking assets), were targeted for closure failed to generate public confidence. To the contrary, the general public, including foreign investors, cognizant of the fact that these sixteen closures would hardly have a significant impact on the "health" of the banking system as a whole, braced for more bank closures.

Third, the situation was made worse when, on November 5, Bambang Trihatmodjo filed a lawsuit against the Governor of Bank Indonesia and the Minister of Finance against the closure of his Bank Andromeda. The fact that Bank Andromeda was back in operation in no time-under the name of Bank Alfa (but using the same building, employees, and a new foreign exchange licence issued by Bank Indonesia) - and that several of the earlier canceled "development" projects of Suharto's family and cronies were suddenly back in operation, convinced many that the Suharto regime was not serious about implementing the agreed-upon reforms. ${ }^{63}$

From late November onwards, things began to go seriously wrong. For starters, the extent of the private sector foreign debt was revealed to be much larger than most analysts had realized. ${ }^{64}$ Many Indonesian firms and financial institutions previously thought to be sound had, in fact, incurred large debt burdens in foreign currencies that they could not service from their rupiah earnings at the prevailing unfavorable exchange rate. These entities were effectively bankrupt. Furthermore, as the international financial markets lost confidence in Indonesian banks, they refused to rollover short-term debt and accept letters of credit. Also, the government decision to limit access to foreign borrowings and to shift public sector deposits from (mainly state-owned) commercial banks to the central bank squeezed liquidity. With banks suddenly not liquid, default by corporate borrowers increased. In this capricious and unpredictable environment, bank deposit runs multiplied amid rumors that a new wave of bank closures was under preparation. By mid-December, 154 banks representing half of the total assets of the system had faced, to varying degrees, some erosion of their deposit base. Also, during December 1997, Bank Indonesia's liquidity support increased from 13 trillion rupiah to 31 trillion rupiah, equivalent to 5 percent of GDP. ${ }^{65}$ Insofar as the liquidity support, paid in rupiah, was needed by banks to meet reductions in dollar deposits, in effect it served to fuel capital flight and, thus,

63 Liebhold, "Rough Road Ahead."

64 While no authoritative figures existed on the size of the debt, it was widely believed to be substantial. Estimates ranges from US $\$ 35$ to US $\$ 70$ billion-much higher than Indonesia's official foreign reserves.

65 Lindgren, et al., "Financial Sector Crisis." 
the continuing depreciation of the exchange rate. ${ }^{66}$ In contrast to the situations in other crisis-hit countries, in Indonesia efforts at sterilization were not successful, reflecting a loss of monetary control by Bank Indonesia. By late December, the rupiah was fluctuating in a wide range around Rp. 5,000 to 6,000 per US dollar.

\section{The Banking Crisis becomes Systemic}

On January 6, 1998, President Suharto presented to the Parliament a draft budget for the fiscal year 1998/99.67 The proposed budget totaled Rp. 133 trillion, a 32.1 percent increase as compared to the previous year's budget of Rp. 101 trillion. The draft budget was based on the "balanced budget" principle (which limits the size of budget deficit to the level that can be financed by foreign aid and loans), and calculated based on assumptions about future conditions: an exchange rate (Rp. 4000 per US\$1), annual economic rate of growth of 4 percent, and inflation rate of 9 percent. The budget also failed to produce the surplus of 1 percent, as stipulated in the IMF agreement. In fact, the expansionary budget was in direct contravention of IMF requirements for a 1 percent budget surplus. ${ }^{68}$ Almost immediately, the markets reacted negatively to the "unrealistic" expansionary budget, a problem further compounded by the collapse (on January 13,1998) of Peregrine, a Hong Kong-based investment bank, which was ruined by a single massive bad loan (US\$265 million) to PT Steady Safe, a local taxi company in Jakarta. ${ }^{69}$ As questions about Suharto's commitment to implementing the program once again came to the forefront, the rupiah headed into a free fall. ${ }^{70}$ The exchange rate dropped from Rp. 5,450 per US $\$ 1$ on January 1 to the infamous "black Thursday" on January 8, when it fell below the "psychological threshold" of Rp. 10,000 to US\$1-leading to panic food buying and social unrest. ${ }^{71}$ In desperation, Suharto hinted at the possibility of issuing Indonesian dollar banknotes that could replace real dollars and be put in a special dollar deposit with high interest rates. The president's daughter, Siti Hardijanti Rukmana (Tutut), promoted Gerakan Cinta Rupiah or "Getar" ("we love the rupiah" movement) to encourage citizens to change their cash dollar holdings into rupiah. However, the initiative was ineffective. The value of the rupiah continued to slide, reaching Rp.

\footnotetext{
66 Moreover, these credits added substantially to the money supply and helped to fuel inflation in early 1998.

67 The budget would take effect from April 1, 1998.

68 Why did Suharto choose to defy the IMF? There seem to be two considerations. First, there was concern that a contractionary budget would force many Indonesian companies, including those owned by his family members and cronies, into bankruptcy, and second, that the elimination of food and fuel subsidies would ignite civil disorder. For details, see Jose Manuel Tesoro, "Gearing for Trouble: Suharto will spend to avert potential unrest," Asiaweek, January 16, 1998.

69 Steady Safe used US $\$ 145$ million to buy 14 percent of a toll road building company owned by Suharto's eldest daughter, Tutut. She was then named to Steady Safe board.

70 A report in the Washington Post (January 8, 1998), mentioned that both the IMF and the United States Treasury were unhappy with Suharto's budget, and questioned his commitment to implementing the agreed IMF program. See, Radelet, "Indonesia: Long Road to Recovery," The Washington Post, January 8, 1998, p. 11.

71 McLeod, "Indonesia in Crisis," p. 225.
} 
10,200 to US $\$ 1.00$ on January 11,1998 . Under these circumstances, the Indonesian government had little choice but to concede to the IMF.

On January 15, in a well-publicized official ceremony witnessed by IMF managing director Michel Camdessus, President Suharto signed his second "Letter of Intent" with the IMF. ${ }^{72}$ It is clear that in the second reform package, the IMF was able to secure a far greater range of reform commitments. Specifically, as stated in the letter of intent, the Indonesian government pledged to implement a fifty-point "Memorandum of Economic and Financial Policies," drafted under the guidance of the IMF. ${ }^{73}$ The program included a range of provisions; on fiscal policy, for instance, it called for the revision of the draft budget for fiscal 1998/99. Recognizing that, given the sharp depreciation of the rupiah and the deterioration in the economy, it was no longer feasible to aim at a surplus of 1 percent of GDP, the memorandum settled for a deficit at 1 percent of GDP. This was to be achieved via expenditure reduction, namely, the elimination of fuel and electricity subsidies. Non-budget expenditures, such as investment fund and reforestation fund, were to be incorporated into the central government budget. Regarding public sector projects, the program called for

... canceling immediately the twelve infrastructure projects that were recently postponed or placed under review. Moreover, budgetary and extra-budgetary support and credit privileges granted to IPTN's airplane projects will be discontinued, effective immediately. In addition, all special tax, customs, and credit privileges for the National Car project will be revoked, effective immediately.

The program also made clear that Bank Indonesia should continue to adopt a tight monetary policy and must be "given full autonomy to conduct monetary policy, and start immediately to unilaterally decide interest rates on its SBI (central bank) certificates. ${ }^{\prime 74}$ In order to improve domestic competition, the program required cartellike marketing arrangements, including those in plywood, cloves, cement, paper and steel, to be eliminated by February 1. That is, that "from February 1, BULOG's monopoly will be limited solely to rice." On investment and foreign trade, the program called for the elimination of restrictions on foreign investment in palm oil, wholesale and retail trade, and content regulations and export taxes on a wide range of products, including leather, cork, ores, logs, sawn lumber, rattan, and minerals. Finally, it called for the deregulation and privatization of selected state-owned enterprises and strategic industries.

\footnotetext{
72 Much was made of this event by the media. As Bresnan notes, "as Suharto affixed his signature, IMF managing director Michel Camdessus stood over him, arms folded across his chest, looking every inch the school-master he was playing in the drama. The photograph of this scene became a symbol of the charged issue at the heart of the negotiations-whether the IMF, and through it the United States, had the right to dictate terms to the Indonesian government in return for help in restoring confidence in its economy." See, John Bresnan, "The United States, the IMF, and the Indonesian Financial Crisis," in The Politics of PostSuharto Indonesia, ed. Adam Schwarz and Jonathan Paris (New York: Council on Foreign Relations Press, 1999), p. 93.

73 See IMF. "Statement by the Managing Director on the IMF Program with Indonesia," News Brief No. 98/2, January 15, 1998; see also IMF. "Indonesia: Memorandum of Economic and Financial Policies," January 15, 1998 (http://www.imf.org/external/np/loi/011598.htm)
} 
Despite the seemingly comprehensive nature of the reform package, it failed to restore market confidence. Part of the problem had to do with the growing rift between the IMF and the Suharto regime. The widely held (and generally correct) perception was that the wily Suharto had signed on to the program only reluctantly, and that he did not intend to follow through with a program that would hurt the business interests involved in the vast financial empire controlled by his children (estimated to be worth around US $\$ 30$ billion $^{75}$ ) or the interests of his close associates. Indeed, even before the IMF team had left Jakarta, Suharto began sending mixed signals regarding his commitment to the program. In an act of open defiance, he made it public that he wanted his long-time friend and the big-spending Technology Minister, B. J. Habibie, to be his vice-presidential candidate (and presumed successor) in the upcoming March polls. ${ }^{76}$ Moreover, as Radelet has aptly noted, the new IMF program-which eased up slightly on fiscal policy and on the capital adequacy ratio required for banks, but otherwise kept the same basic strategy as the first policy-was misguided. ${ }^{77}$ It was misguided because excess demand was not at the root of Indonesia's problems, and the capital withdrawals well underway meant that the economy was already contracting significantly. The initial fiscal tightening simply added to the contraction, further undermining investor confidence and fueling capital flight. ${ }^{78}$ Finally, the structural reforms envisaged in the program, while necessary over the long-term, did not provide any concrete solutions to the immediate problems of the banking and currency crisis. Specifically, the program did not articulate a clear strategy to resolve the banking sector problems (i.e. it did not have concrete bank rehabilitation and restructuring measures that could restore confidence in the banking system), nor did it provide a plan to deal with Indonesia's short-term foreign debt. The market's lack of confidence was reflected in the continued downhill slide of the rupiah. Less than a week later, on January 22, the rupiah fell to an unprecedented all-time low of Rp. 17,000 to the US dollar. Moreover, left unattended, the banking sector problems turned into a full-fledged systemic crisis, with liquidity support from Bank Indonesia exceeding over sixty trillion rupiah (about 6 percent of 1998 GDP), with the risk of hyperinflation and complete financial sector meltdown looming menacingly on the horizon.

Finally, on January 27, with their backs against the wall and under pressure from the IMF, the Indonesian government took steps to deal with the banking sector problems. It announced a three-point "emergency plan." First, the government announced a blanket guarantee of the rupiah and foreign currency denominated debts of all domestically incorporated banks. The guarantee extended to deposits and most

74 SBI's, or "Sertifikat Bank Indonesia," are issued every Wednesday with a one month duration, but beginning in October 1998, Bank Indonesia also began to issue three-month SBI's.

75 See Philip Shenon, "For the First Family of Indonesia, an Empire Now in Jeopardy," New York Times, January 16, 1998.

76 It was well known that Habibie, who had major financial stake in almost every business activity in Indonesia, epitomized the unscrupulous crony capitalism and the perverse business subculture. It was no secret that the IMF and the United States did not want him to be vice-president. See Bresnan, "The United States, the IMF," pp. 92-4.

77 Radelet, "Indonesia: Long Road to Recovery."

${ }^{78}$ Of course, several months later the IMF recognized this fatal mistake and eased up on its fiscal targets in Indonesia (as it did in Korea and Thailand), but the damage had been done. 
types of creditor claims-excluding subordinated debt. ${ }^{79}$ The blanket guarantee on deposits (confirming Bank Indonesia's determination to exercise its last-resort function, even if it exacted a heavy toll) was designed to stem bank runs and thereby stabilize the banking system. In addition, Bank Indonesia placed restrictions on credit growth and announced it would set weekly ceilings on the maximum interest rates that banks could pay on deposits. Second, a new regulatory body for the banking industry, the Indonesian Bank Restructuring Agency (IBRA), was established under a presidential decree for a period of five years. ${ }^{80}$ Established as an "independent" agency, reporting to the Ministry of Finance (but with advisors from the New Yorkbased investment banks Lehman Brothers and JP Morgan), IBRA's task was to take over and rehabilitate weak banks and administer the government's guarantee program for bank debts. The IBRA was also empowered to establish a separate asset management entity called the Asset Management Unit (AMU) to take over nonperforming assets from banks that were either to be liquidated or merged into stronger institutions. Not only was the Banking Law amended to give the AMU the power needed to deal with problem banks, all banks were required to have their loan portfolios reviewed by internationally recognized audit firms by the end of 1998 . Also, IBRA was given the responsibility for collecting from the majority shareholders of the private banks the amounts that their banks owed Bank Indonesia in connection with the liquidity support that they had received. Third, a framework for handling corporate restructuring was proposed; in particular, the emergency plan recommended a temporary voluntary suspension of corporate external debt payment. However, the government made it clear that there would be no use of public financing, guarantee, or subsidy to erase the debt and reimburse unguaranteed creditors looking for financial redress.

Although IBRA was hardly an autonomous agency (its effectiveness was compromised by a weak legal and regulatory framework and also by its need to obtain political authority, even for technical operations), the fact that its restructuring agenda looked feasible raised hopes that finally something substantive was being done to deal with the country's banking problems. Based on its review of the banks' financial position, IBRA divided banks that had received substantial liquidity support from Bank Indonesia (i.e. more than 500 percent of their total equity) into categories $A$ and B. Category A banks included those that had received liquidity support equal to or in excess of 75 percent of their total assets, and Category B banks were those that received less than 75 percent, but still equal to or in excess of two trillion rupiah. Category A banks were to be liquidated, whereas Category B banks were to have the rights of their shareholders suspended and their existing managers replaced by IBRAwhich would assume full management control ${ }^{81}$ IBRA also made it explicit that the former majority shareholders of the suspended banks must pay the government two separate amounts: first, the outstanding negative balance that their respective bank

\footnotetext{
79 The guarantee was due to expire on January 31,2000 . At that time it would be replaced by a deposit insurance scheme. The guarantee was retroactively applied to the sixteen closed banks. The guarantee, however, excluded debts of bank owners and subordinated debts.

80 Prior to the creation of IBRA, Bank Indonesia was the primary supervisory body for the banking industry. IBRA is known in Bahasa Indonesia as Badan Penyehatan Perbanken Nasional (BPPN).

81 For details, see Republic of Indonesia Presidential Decree No. 27/1998, January 26, 1998.

http://www.indoexchange.com/babong/general/bppn/who/tengah.html
} 
had accumulated with Bank Indonesia, and second, the amount by which their respective banks' intra-group lending exceeded the affiliated lending limits before September 21, 1998. ${ }^{82}$ The announcement of this new and ambitious plan was able to slow bank runs and restore a modicum of financial stability. On January 28 , the exchange rate recovered to Rp. 12,500 per US dollar, and appreciated further in the subsequent days to rally at Rp. 9,950 per US dollar on February 16. IBRA's early actions resulted in the closure of a large number of banks which had severely negative net worth and no significant value or franchise importance to the system. Specifically, by February 14, fifty-four distressed banks (consisting of four state banks, thirty-nine private national banks, and eleven regional development banks comprising 36.7 percent of the banking sector) that had borrowed heavily from Bank Indonesia were brought under the auspices of the IBRA. The four state-owned banks (Bapindo, Bank Bumi Daya, Bank Dagang Negara or BDNI, and Bank Exim), accounted for 24.7 percent of the liabilities of the banking sector. 83

However, just when the government's plan seem to be working-making believers of some of the cynics-interference by Suharto once again undermined the efforts. ${ }^{84}$ First, Suharto refused to publicize the operations of IBRA. As a result, IBRA officials had to work over the following weeks against a public perception that IBRA was a "paper-tiger" and still not operational. As the IMF study reports, "the initial workings of IBRA were not apparent to the public, there was confusion as to the authorities' intentions, and the momentum generated by the January 27 announcement was largely lost." 85 More damaging, on February 17, Suharto abruptly fired one of the few reformers in his regime, the highly respected Governor of Bank Indonesia, Sudradjad Djiwandono, less than two weeks before the official end of his tenure. ${ }^{86}$ It was reported that Suharto fired Djiwandono after the governor "had argued that Suharto was about to subvert an economic recovery plan he reluctantly signed just last month with the IMF."87 In late February, Suharto dismissed the head of IBRA and, to make matters worse, started making increasingly hostile remarks about the IMF, culminating in a reported statement to a largely Muslim audience that the IMF package could not be implemented because it violated Article 33 of the Indonesian constitution. If Suharto's obscurantism and well-worn pattern of double-entendres and half-measures frustrated the IMF and the donor countries, his plan to create a fixed exchange rate system for the volatile rupiah through a currency board in direct opposition to the IMF, the United States, the European Community, Japan and other donor governments was more than could be tolerated.

\footnotetext{
82 Karene Witcher and Jay Solomon, "Jakarta Takes Over Much of the Bank System," Asian Wall Street Journal, August 24, 1998. 
While rumors that Indonesia might adopt a currency board had been around for weeks, by mid-February Jakarta began to send implicit messages that it would unilaterally establish a currency board, unless the Fund came up with a better alternative for strengthening the rupiah. 88 On February 11, the Minister of Finance announced that the government was preparing steps towards setting up a currency board system. Following the appointment on February 17 of US-trained economist, Sjahril Sabirin, as the new Bank Indonesia Governor, and of John Hopkins University economist, Steve Hanke, as adviser to President Suharto's economic council, the Indonesian government embarked on a media blitz to make its case for a currency board regime. The government now claimed that, unlike an ordinary exchange-rate peg, the predictability and rule-based nature of a currency board would impose strict discipline on the government-preventing it, for example, from abusing the central bank's printing presses to fund large deficits. Using the example of the Hong Kong dollar-which had been officially fixed at HK\$7.80 per American dollar since the board was introduced in 1983, and which had weathered the crisis reasonably wellsupporters argued that, since the currency board holds extremely low-risk interestbearing bonds and other assets denominated in the anchor currency, it not only encourages arbitrage, but also offers an effective barrier against speculative attacks and rapid currency appreciations. Moreover, they claimed that currency boards provide stability to the banking and financial system by maintaining market-adjusted interest rates and prudentially controlling destabilizing international capital flows.

While the IMF, in principle, is not opposed to emerging economies establishing currency boards, it strongly opposed the Indonesian plan-threatening to withhold funding-because it felt that a currency board was a "quick-fix" and an ultimately unsustainable solution for Indonesia. ${ }^{89}$ Rather, the IMF argued that it was important for Indonesia to implement the agreed-upon reforms before establishing a currency board. This was based on sound economic reasoning: a currency board arrangement can only work effectively if the banking system has the capacity to tolerate significant movements in domestic interest rates. Without this capacity, the currency board arrangement will induce a conversion of deposits into foreign exchange, further shrink the monetary base, and greatly increase interest rates. Since a currency board must hold reserves of foreign exchange (or gold or some other liquid asset) equal at the fixed rate of exchange to at least 100 percent of the domestic currency issued, the IMF appropriately concluded that Indonesia's US\$12 billion in disclosed foreign exchange reserves (as of March 20, 1998) and a foreign debt of $\$ 130$ billion were simply inadequate to back the estimated 24 trillion rupiah in circulation-the reserves would be drained in a few weeks. ${ }^{90}$

Moreover, the IMF had good reason to suspect that the Suharto regime would dip into the loans to support the currency board-after all, it was already injecting massive doses of liquidity to bail out the country's weak banking system. The IMF

\footnotetext{
88 Peter Passell, "Economic Scene: In Indonesia, Slowdown on a Risky Bet," New York Times, February 19, 1998.

89 In February 1998, a leaked letter from the IMF's managing director threatened the withdrawal of financial support if a currency board was established. C. Johnson, "Survey of Recent Developments," Bulletin of Indonesian Economic Studies 32,2 (1998): 27-8.

90 Jose Manuel Tesoro, "A Quick Fix? Maybe Not," Asiaweek, March 6, 1998.
} 
found the Hong Kong example as spurious. In Hong Kong, the Exchange Fund is committed to 100 percent foreign currency backing for Hong Kong dollar bank notes, and the Hong Kong Monetary Authority (HKMA) has an explicit mandate to act as an official lender of last resort and has been involved in open market operations since 1990. Further, Hong Kong (unlike Indonesia) has formidable foreign reserves totaling over US\$85 billion (in 1997-98) to cover the currency in circulation plus demand deposits. This gave the HKMA tremendous autonomy to raise short-term interest rates to make it expensive for speculators to obtain Hong Kong dollar credit. Unlike Indonesia's banks, Hong Kong's well-regulated and capitalized banks, which had very low levels of non-performing loans, could cope with the increases in short-term interest rates that might be needed to defend the currency board. Finally, with justifiable reason, the Fund remained highly suspicious of the "Suharto plan," under which the rupiah's rate would be 5,000 to the dollar, or about twice as strong as the then current rate. Since a currency board is committed to exchanging, on demand and without any limit, foreign currency and local currency, and in some cases must also exchange bank reserves at a pre-announced exchange rate, the IMF felt that the currency board was a ploy to allow Suharto's children and cronies to retrench discretionary and egregious rent-seeking structures, quickly change their substantial rupiah holdings into dollars at an artificially high rate, and then move those funds into offshore accounts. It should be noted that if capital outflows are sufficiently large, a currency board could collapse because of a shortage of foreign assets. In Indonesia, where the government in 1997-98 could not even provide complete cover for the domestic currency, the currency board would simply wipe out its remaining foreign currency reserves before the entire domestic currency stock had been converted.

\section{The End of the New Order and Conversion to Orde Reformasi}

In the ensuing weeks, as Suharto vacillated and stalled, the economic downturn deepened, and the Indonesian economy was brought to the brink of total collapse. ${ }^{91}$ Liquidity support to the banking sector continued to increase-largely to meet continuing deposit withdrawals-further eroding public confidence in the banking reforms underway. As tensions between the Suharto regime and the IMF intensified, the IMF (on March 6) announced the suspension of the second installment of the bailout package. ${ }^{92}$ Nevertheless, on March 10, the People's Consultative Assembly, chose, by acclamation, Suharto as president and B. J. Habibie as vice-president. ${ }^{93}$ With the seventy-seven-year-old Suharto now set to serve an unprecedented seventh five-year term as president (ending in the year 2003), all hopes for an early resolution

\footnotetext{
91 James Levinsohn, Steven Berry, and Jed Friedman, "Impacts of the Indonesian Economic Crisis: Price Changes and the Poor," NBER Working Paper, 7197. June, 1999.

92 Johnson, "Survey of Recent Developments," p. 27.

93 Following the 1945 Constitution, the People's Consultative Assembly (PCA) met quinquennially, within a few months after a parliamentary election, to elect the president and vice-president and establish the broad outlines of state policy for the next five-year term. The parliament or DPR (Dewan Perwakilan Rakyat) consisted of five hundred members-four hundred of these were elected and the remaining one hundred were military appointees. The so-called super-parliament, the (MPR) Majelis Permusyawaratan Rakyat or People's Consultative Assembly, consisted of all members of the DPR, plus an additional five hundred appointees made by Suharto.
} 
104 Shalendra D. Sharma

of the stalemate with the IMF were dashed. Indeed, in an open act of defiance to the IMF and bilateral donors, Suharto refused to appoint reformers to key cabinet positions. Instead, his choose loyalists and a close circle of cronies, including his eldest daughter, Tutut, and his closest business crony and golf partner, Bob Hasan, among others. It seemed that the old corrupt establishment was entrenching itself for the long haul, despite increasing demands (both domestic and international) for reform.

In spite of this unpropitious environment, the IMF and the Indonesian government did reach their third agreement on April 9.94 The new agreement reiterated the points agreed in the earlier ones, and added some more-making a total of 117 specific requirements, including more specific targets and a time-table for implementation. However, even before the ink was dry on the agreement, Suharto implicitly dismissed what he had just signed, calling instead for an undefined "IMF plus" program. This time, having witnessed the show before, the markets failed to react to the agreement. However, the same could not be said of the growing popular opposition to Suharto rule. Following weeks of largely peaceful student demonstrations at dozens of universities across the country, events soon turned violent after a harsh crackdown by the security forces. The calls for Suharto's resignation grew louder following the government's ill-advised decision to increase fuel prices sharply (up 71 percent for gasoline and 25 percent for kerosene) in early May.95 Between May 13-17, 1998, the pent-up frustrations exploded. Widespread and violent rioting occurred simultaneously in many cities and towns throughout the country and, most tragically, in Jakarta, where over a thousand people were killed. Under intense domestic and international pressure, and in the face of mass demonstrations, Suharto abruptly resigned on May 21, 1998 after thirty-two years as president. It marked the beginning of the end of the "New Order" regime.

In accordance with the constitution, vice-president B. J. Habibie was sworn in as president to serve out the remainder of Suharto's five-year term. Habibie inherited a nation in crisis. Lacking popular support and legitimacy, the regime watched helplessly as civil law and order collapsed and armed gangs arbitrarily targeted the symbols of the "New Order" - in particular, Sino-Indonesian businesses-engaging in looting and destruction with impunity. The wanton destruction of property and infrastructure severely disrupted economic activity, especially exports so critical to economic recovery. In the ensuing chaos, expatriates, businesses, and capital fled Indonesia; members of the IMF and World Bank delegation in Jakarta joined the exodus. Both during and immediately after the riots, there were massive runs on all banks, in particular, Bank Central Asia, the nation's largest private bank, accounting for 12 percent of total banking sector liabilities. Bank Indonesia, in conjunction with two of the state banks, supplied over 30 trillion rupiah in cash to Bank Central Asia over the week following May 16 as deposits were withdrawn. Finally, on May 29, Bank Central Asia was brought under the auspices of IBRA, and the owners' rights suspended. ${ }^{96}$ In

\footnotetext{
94 IMF, "Indonesia: Supplementary Memorandum of Economic and Financial Policies," April 10, 1998, (http://www.imf.org/external/np/loi/041098.htm)

95 The fuel price increase (although not its precise timing) was one of the IMF conditions. It is not clear if the IMF wanted the measure to be implemented incrementally or at once. In any case, the Suharto government implemented the measure at once-severely impacting the vast majority of Indonesians.

96 Enoch, "Interventions in Banks."
} 
this climate of chaos and uncertainty, the rupiah fell below 12,000 to the dollar by the end of May and continued to nosedive, reaching Rp. 16,500 against the dollar on June 17-a cumulative depreciation of 85 percent since June 1997.

In the face of growing social unrest and international pressure, President Habibie, in a surprise volte-face, accepted the charge that the New Order regime was undemocratic, promising now an Orde Reformasi (Reformation Order). To show his commitment, the Habibie government immediately freed the press from the draconian constraints that had been in force under Suharto and revoked the law that limited the number of political parties to two. Habibie also announced that new parliamentary elections (to be preceded by the rewriting of New Order election and political party laws) would be held in mid-1999. In the economic realm,

President Habibie and most of the new cabinet showed a greatly increased commitment to implementing the IMF program. Specifically, immediate pressure was off Bank Indonesia to do anything more than restore financial stability. There was significant easing of political pressures to bail out banks, and no apparent pressure on BI to reduce interest rates prematurely again." 97

Moreover, Habibie affirmed that the Coordinating Minister for the Economy, Ginandjar Kartasasmita, the official most trusted by the IMF in the last days of Suharto's presidency, would remain in office-this despite a long history of political, policy, and personal conflict between Habibie and Ginandjar. Perhaps what pleased the IMF (not to mention a section of the Indonesian business community) most was Habibie's announcement that the University of Indonesia economics professor, Prof. Widjojo Nitisastro, would have an enhanced advisory role in the government. ${ }^{98}$ On June 24, the IMF and the Indonesian government signed the "Second Supplementary Memorandum of Economic and Financial policies"99-a revised version of the economic program signed on April 10. The new memorandum bleakly noted that "with the disruptions to economic activity and damage to business confidence in recent weeks, it is now expected that real GDP will decline by more than 10 percent in 1998."

Bad as this news was, there was more to come. In late June 1998, audit reports on banks that had been taken over by IBRA-reports that were conducted by international accounting firms during the spring and summer of 1998-were leaked to the press. The results were devastating, showing levels of nonperforming loans ranging from 55 percent to more than 90 percent of the banks' portfolios. ${ }^{100}$ For most of these banks, the loans' portfolios were dominated by memo-lending. By early August, the results of the portfolio reviews for a group of sixteen large banks, all of them non-IBRA (except for Bank Central Asia), became available. The results showed that the

\footnotetext{
97 Kenward, "What Has Been Happening," p. 124.

98 Professor Widjojo Nitisastro is considered the chief architect of the New Order development policy. He served as Suharto's chief economic adviser from the mid-1960s to the early 1980s. In later years he was frequently called upon to rescue the economy from the depredations caused by Suharto's children, and big spenders like Habibie and Ginandjar. Widjojo's commitment to market-oriented macroeconomic policies reassured both the IMF and sections of the Indonesian business community.

99 IMF, "Indonesia: Second Supplementary Memorandum of Economic and Financial Policies," June 24, 1998), (http://www.imf.org/external/np/loi/062498.htm)

100 Enoch, "Interventions in Banks," p. 16.
} 
financial condition of these banks was also very weak. Given that many of these banks would have been expected to be among the strongest in the country, these reviews confirmed the deep insolvency of the banking system as a whole. The immediate consequence was shock that the state of the banks were so bad, but beyond that, the leak put an end to denial of the seriousness of the banking problems and forced the Indonesian authorities to recognize that implementation of banking reforms was of utmost urgency.

\section{Towards Banking and Corporate Sector Reforms}

The massive insolvency of the Indonesian banking system called for a major restructuring of the entire sector. In September 1998, Bank Indonesia outlined an ambitious multi-billion dollar bank recapitalization plan, ${ }^{101}$ and in October, the Indonesian parliament passed amendments to the banking law that modified previous requirements regarding bank secrecy and ended restrictions on foreign ownership of banks. These amendments also strengthened the legal powers of IBRA and AMU, enabling them to operate more effectively-for instance, to be able to transfer assets and to foreclose against a nonperforming debtor. To show that it was serious about implementing the plans, the government, in mid-September, announced that four stateowned banks (BDN, EXIM, BBD, and Bapindo), along with the corporate business of a fifth state bank (BRI), would be merged into a new institution, Bank Mandiri. Bank Mandiri was established on September 30 as the holder of 100 percent of the shares of the component banks. ${ }^{102}$ Moreover, efforts were made to strengthen the prudential and regulatory framework. Specifically, three new regulations in the area of loan classification, provisioning, and debt restructuring operations came into effect in late December 1998. In the area of liquidity management, banks were required to submit a liquidity report twice monthly for their global consolidated operations (this requirement became effective in early 1999). Among other things, the liquidity report had to contain both a foreign currency liquidity profile and a rupiah and foreign currency profile. Also, beginning in April 1999, banks were to be required to publish their financial statements quarterly. Last, by the end of 2000, banks would be required to comply with a minimum capital adequacy requirement of 8 percent. ${ }^{103}$

The more difficult challenge lies in the area of bank recapitalization. Keeping in mind that nonperforming loans are estimated at 60-85 percent of all loans, and that bank recapitalization costs are estimated at a staggering Rp. 643 trillion (about US\$89 billion), or 60 percent of GDP, we must recognize that it will likely take several years to restore the financial sector to health. ${ }^{104}$ The first major step towards

101 Under the recapitalization plan, for every rupiah of fresh capital injected into banks that qualified for recapitalization, the government would put up Rp. 4. In return for its injections of capital (which were to be refunded by bond issue) the government would receive equity stakes in the banks. Bank owners would then have three years to redeem part or the entire government stake.

102 Following the legal merger in July 1999, the government began plans to privatize Bank Mandiri and the three remaining state-owned banks.

103 Syahril Sabirin, "Recent Developments in the Indonesian Economy," presentation to Banque de France, March, 1999, Mimeo.

104 Lindgren, et al., "Financial Sector Crisis," p. 65. 
recapitalization of private banks began in early 1999. On the basis of a review carried out by independent auditors of all state banks, nationalized banks, regional banks and private banks, the Indonesian authorities ranked banks into three categories according to their capital adequacy ratio. Under the new ranking system, banks in category $C$ (those with a capital adequacy ratio of less than negative 25 percent) were to face liquidation. By March 1999, thirty-eight banks, all deeply insolvent and with no hope of recovering, had been closed and "their owners will be required to repay their connected [i.e. memo] lending." 105 Indeed, the government announced a list of the two hundred largest defaulting borrowers and began the process of actively collecting from the twenty largest defaulters. Nine Category B banks ( those with a ratio of negative 25 percent to less than 4 percent) were deemed eligible for recapitalization, while seven category B banks were taken over by IBRA. These banks were in serious financial difficulty, although it was stated that, due to their extensive branch networks, they would be taken over (and not closed) to minimize disruption to the payments system. Former owners of these institutions were blocked from further roles in the management of banks. The intention was to restructure these banks, improve their financial performance, reduce their burden on the budget, and prepare them for privatization. All category $A$ banks (those with a capital adequacy ratio of 4 percent or higher) were allowed to continue business. Seven private banks were recapitalized in 1999, and four state-owned banks, comprising half of the assets of the banking sector, were merged into one and recapitalized.

Cognizant of the fact that Indonesian taxpayers were providing the funds, authorities required that two criteria be met by banks seeking recapitalization. First, all banks were required to submit business plans that showed their viability over a threeyear period, and their managers were required to pass tests ensuring that they were technically competent to run a bank. And second, since many of the banks eligible for recapitalization were owned by some of the country's major conglomerates, the existing shareholders were required to provide at least 20 percent (in cash) of the total funds necessary to restore the bank's capital adequacy ratio to 4 percent before IBRA would put in any funds. Overall, in the past two years, the Indonesian banking sector has been significantly consolidated. Since mid-1997, the number of private domestic banks has been nearly halved through closures or state takeovers. By the end of 1999, banks under state control held about 70 percent of liabilities, compared to 40 percent before the crisis. 106 Nevertheless, it remains to be seen whether recapitalization will result in a healthy banking sector.

As of mid-1999, the public contribution to financial sector restructuring has been equal to 51 percent of GDP. The largest share of this has been used to recapitalize banks and provide liquidity support. ${ }^{107}$ It is important to keep in mind that IBRA is financed by a mix of medium- and long-term government-guaranteed bonds, some inflation-indexed, others not. These bonds pay high rates of interest, averaging 14 percent annually. IBRA has exchanged these bonds for the worst nonperforming loans in the banking system (the so-called Category 5 loans). In the process, IBRA has

\footnotetext{
105 Government of Indonesia, "Government of Indonesia Announces Sweeping Reforms to the Bank System," press release, 1999, (http://www.bi.go.id.Intl/press.html)

106 Lindgren, et al, "Financial Sector Crisis," p. 65.

$107 \mathrm{Ibid}$.
} 
acquired billions of dollars worth of assets-measured at face value, not market value. ${ }^{108}$ While IBRA has been given substantial extrajudicial powers to deal with recalcitrant debtors, it remains to be seen what portion of the loans IBRA will be able to recover. So far the progress has been slow. Indeed, the implementation of the program came to an abrupt halt in August 1999 with the outbreak of the Bank Bali scandal. The scandal allegedly implicated senior officials at Bank Indonesia, the Ministry of Finance, and IBRA. These senior officials were accused of cooperating in a deal that arranged for a Habibie-connected company to pay US $\$ 80$ million to a private bank, Bank Bali, in order to recover claims that were in fact already guaranteed by the government. This scandal led to the suspension of the IMF funds in September 1999.

As noted earlier, the level of nonperforming loans in the Indonesian banking system is simply unprecedented. Since coming into operation, the AMU has taken over loans from a variety of institutions: closed banks, banks that have been taken over, stateowned banks, and banks participating in the recapitalization schemes. However, not all of these loans have been transferred. Moreover, because of its limited resources, IBRA has been unable to administer all of these loans on its own. In fact, bad loans of less than five billion rupiah are handled by the individual banks, bad loans valued at between five billion and twenty-five billion rupiah are subcontracted back to the individual banks (implementation remains under the supervision of the AMU), and bad loans in excess of twenty-five billion rupiah are handled directly by the AMU. In addition to loans, some non-core assets, including automobiles and office equipment, have been transferred to the AMU. According to the Indonesian government, the total amount of problem debt transferred to the AMU as of January 2000 was approximately 250 trillion rupiah. ${ }^{109}$

By year-end 1997, domestic private corporations had borrowed US $\$ 53.6$ billion from foreign banks, which left the corporate sector (as well as Indonesian banks exposed to these corporates) highly vulnerable to sudden depreciation. By late 1998, of the estimated US $\$ 118$ billion corporate debt, nearly 60 percent was owed to foreign creditors and about half of the remaining 40 percent was denominated in foreign currency. This, in effect, rendered the Indonesian corporate sector systematically vulnerable to large-scale depreciation of the rupiah. ${ }^{110}$ Indeed, the widespread rupiah depreciation that took place during the height of the crisis drove almost half of Indonesian corporations into insolvency and caused many more corporations difficulties in meeting their debt-servicing obligations.

108 According to Hufbauer, as of August 1999, IBRA had acquired some Rp. 500 trillion (US\$85 billion) of assets, measured at face value, not market value. Gary Hufbauer, "Cleaning Up the Financial Wreckage: An Eight-Point Program for Indonesia," Policy Paper (Washington, D.C.: Institute for International Economics, 1999).

109 For details, see Gregory Root, Paul Grela, Mark Jones, and Anand Adiga, "Financial Sector Restructuring in East Asia," in Managing Financial and Corporate Distress: Lessons from Asia, ed. Charles Adams, Robert Litan, and Michael Pomerleano (Washington, DC: The Brookings Institution Press, 2000), pp. 192-3.

110 Masahiro Kawai, Ira Lieberman, and William Mako, "Financial Stabilization and Initial Restructuring of East Asian Corporations: Approaches, Results and Lessons," in Managing Financial and Corporate Distress: Lessons from Asia, ed. Charles Adams, Robert Litan, and Michael Pomerleano (Washington, DC: The Brookings Institution Press, 2000), p. 82. 
The Indonesian government's strategy for corporate restructuring has included three elements. First, the Jakarta Initiative and the Jakarta Initiative Task Force (JITF) were introduced in September 1998 to facilitate voluntary negotiations between debtors and creditors for corporate restructuring and to provide a regulatory "one-stop shop" for administrative procedures pertaining to debt resolution. The Jakarta Initiative introduced a set of principles based on the London Approach to guide voluntary outof-court corporate restructuring. ${ }^{111}$ The JITF was intended to facilitate negotiations between debtors and creditors and to obtain necessary regulatory approvals for deals. As of April 2000, while 320 companies with US $\$ 23$ billion in debts have registered with the JITF, only six cases (totaling less than US\$1 billion in debt) have been resolved. Poor enforcement of laws to protect creditors has given debtors little incentive to agree to restructuring deals likely to result in debt-to-equity conversions and substantial dilution of their shareholdings. ${ }^{112}$ Second, a new bankruptcy system and a special commercial court were introduced to provide a credible threat. Third, the Indonesian Debt Restructuring Agency (INDRA) was established under the Frankfurt Agreement in June 1998 to provide foreign exchange cover for Indonesian corporations with foreign currency-denominated debt once they have reached debt restructuring agreements. Despite these initiatives, corporate debt restructuring has proceeded slowly. Implementation of the bankruptcy law must be improved if the process is to be more successful. Specifically, voluntary mechanisms for restructuring corporate debt will have greater appeal if creditors can reasonably expect to be able to speedily enforce their claims against debtors through legal means, should voluntary methods fail.

\section{Democracy and Reforms}

On June 7, 1999, Indonesia held a democratic election for the first time since 1955. Forty-eight political parties competed, with twenty-one winning at least one of the 462 contested seats in the five-hundred-member national Dewan Perwakilan Rakyat or parliament (the additional thirty-eight seats are held by appointed armed forces delegates). Simultaneous elections were held for legislatures in twenty-six provinces and more than three hundred districts and municipalities. Over 90 percent of registered voters turned out for the three-level elections. ${ }^{113}$ At the national level, the PDI-P (Partai Demokrasi Indonesia-Perjuangan) won 34 percent of the vote and 153 seats in parliament; Golkar (Golongan Karya) won 22 percent of the vote and 120 seats; the PKB (Partai Kebangkitan Bangsa) won 12 percent of the votes and 51 seats; PPP (Partai Persatuan Pembangunan) won 10 percent of the votes and 58 seats; and

111 The London Approach, formulated by the Bank of England in the 1970s and developed further in the 1990 s, consists of a set of non-binding principles to guide debt restructuring processes. It has three objectives: to minimize losses to creditors and other parties; to avoid unnecessary liquidations of fundamentally viable debtors; and to ensure continued financial support to viable debtors.

112 Kawai, et al., "Financial Stabilization," p. 92.

113 At that time, East Timor was still the twenty-seventh province, but did not participate in the elections. See, William R. Liddle, "Indonesia in 1999: Democracy Restored," Asinn Survey XL,1 (January-February, 2000): 32-42. 
110 Shalendra D. Sharma

PAN (Partai Amanat Nasional) won 7 percent of the votes and 34 seats. ${ }^{114}$ On October 20, 1999, the seven-hundred-member Majelis Permusyawaratan Rakyat (People's Consultative Assembly) met to elect a new president and vice-president to govern the world's fourth-most-populous nation for the next five years. The presidential election was won by long-time democratic activist and PKB leader, Abdurrahman Wahid (also fondly known as Gus Dur), who won 373 votes against PDI-P's Megawati Sukarnoputri with 313. On October 21, Megawati was elected by an overwhelming majority as vice-president.

The new government committed itself to the rapid implementation of the economic reform measures, and immediately after the October elections, it signed a new letter of intent with the IMF. However, policy-making in a deeply fragmented parliament with its competing parties and factions has not been easy. Moreover, President Wahid's well-intentioned decision to form a "national unity cabinet" created its own problems. ${ }^{115}$ In the economic arena, fragmentation of the cabinet was reflected in the fragmentation of economic decision-making authority between a number of competing cabinet ministers and their outside advisers. This delayed the implementation of reforms-in particular, corporate debt restructuring-culminating in the embarrassing suspension of US $\$ 400$ million in IMF support in late March $2000 .{ }^{116}$ However, the IMF action seemed to act as a wake-up call. Since that action, the Wahid administration has made concerted efforts to implement economic reforms, including addressing the problem of corruption and the Suharto family wealth.

To compensate for the problems associated with the Bank Bali scandal and to renew its commitment to reforms, the Wahid government, gave IBRA extraordinary powers (the so-called PP17 powers), effective October 1999, to seize assets of uncooperative debtors. IBRA used its PP17 powers for the first time in December 1999, seizing two properties, including fourteen hectares of land in Jakarta from a firm owned by a Suharto family member. Similarly, in an effort to energize the JITF, the government has approved time-bound procedures for JITF mediation of its cases and agreed that the JITF may refer cases of uncooperative debtors to the government's Financial Sector Policy Committee for action by the attorney general's office in Bankruptcy Court. Also, the government has made concerted efforts to address the negative perceptions about governance in judicial processes. There is the realization that delays in corporate debt restructuring will impede economic recovery. Finally, while Indonesia undoubtedly faces daunting challenges to reforming its banking and financial sector, the realization that a weak banking sector made Indonesia particularly vulnerable to the Asian economic crisis, and deepened the depth and duration of the crisis, is strong incentive to move forward with the reforms.

\footnotetext{
114 Two other parties with significant support were PBB (Partai Bulan Bintang) and PK (Partai Keadilan), which won 2 percent and thirteen seats and 1 percent and six seats, respectively. See Liddle, "Indonesia in 1999," p. 33.

115 Stephan Haggard, The Political Economy of the Asian Financial Crisis (Washington, DC: Institute for International Economics, 2000).

116 The IMF delayed its disbursement because it found that Indonesia had made almost no progress on the promises it made in January 2000.
} 